\title{
Biologic and Economic Performance of Broiler Chickens Fed Cassava Root Meal "Garri" as a Substitute for Maize.
}

\author{
G.S. Ojewola, ${ }^{1}$; E.A, Ebele. ${ }^{1}$; and Olojede.A.O ${ }^{2 .}$ \\ ${ }^{I}$ Department of Animal Nutrition and Forage Science, Michael Okpara University of Agriculture, Umudike. \\ P.M.B. 7267.Umuahia.Abia State. Nigeria. \\ ${ }^{2}$ National Root Crop Research Institute Umudike, P.M.B 7006 Umuahia, Abia State. Nigeria.
}

\begin{abstract}
: 56days experiment was carried out to study the effect of substituting dietary maize with graded levels of cassava root meal "Garri" in broiler chicken diet. The percentage dietary maize in the diet was gradually substituted with cassava root meal at 0\%, 10\%, 20\%, 30\%, 40\%, 50\%, 60\%, 70\%, 80\%, 90\%, and 100\% respectively in a Completely Randomized Design. Two hundred and twenty (220) day-old unsexed broiler chicks were randomly assigned to the treatments. Each treatment consists of 20 chicks replicated twice with 10 chicks per replicate. Mean weight gain and feed-to-gain ratio of birds fed diets 1 and 2 were significantly $(P<0.05)$ superior to the others while birds fed diets 3 to 11 had their weights and feed-to-gain ratio slightly depressed, though comparable and within the range of acceptable values. Weights $(g)$, cut-parts $(g)$, percent dressed weights and cut-parts were significantly $(P<0.05)$ influenced with the mean dressed weight ranging from $1425 \mathrm{~g}(D 6$ and 7) to $2272.50 \mathrm{~g}(\mathrm{D} 1)$. Birds fed diets 1 and 6 respectively gave the highest (73.33\%) and least (60\%) values, though the values followed no definite pattern. $P C V, H B C$ and ALP were not significantly $(P>0.05)$ influenced, but others were. Valuesobtained were also within the range reported for healthy birds. The cost variables were significantly $(P<0.05)$ influenced and showed an inverse relationship with the increase substitution of maize with cassava root meal. In conclusion, cassava root meal "Garri" might have depressed revenue slightly it cannot be said to be unprofitable, so it is recommended even at 100\%.
\end{abstract}

Keywords: maize, cassava root meal, broiler chicken, poultry, nutrition.

\section{Introduction}

The ever increasing Nigerian population without a corresponding increase in per capital food production, real income and skills required for wealth creation is responsible for the poverty and lack of food security that is presently prevalent in Nigeria. Our inability to also adequately exploit the abundant plant and animal resources at our disposal for our own advantage has further compounded our situation. For instance, Nigeria is currently the largest producer of cassava in the world, with an output of over 45 million tones of tuberous roots. (FAO, 2011;Adekanyeet al.,2013). Inspite of this achievement, we are yet to fully exploit this to our utmost economic benefit. Cassava was for several years a stable food in human diets and a source of income for subsistent farmers in Nigeria. But with the increasing research and or technological innovations into its production, processing methods and usage, it is becoming a major resource in the livestock and industrial sector of our nation. This opportunity must therefore be exploited maximally to our collective advantage.

According to Oke (1978) and FAO (2011), cassava, a dietary energy supplying resource has the capacity to provide 13 times higher energy/ha than maize or guinea corn. And according to Sauvant et al. (2004), the metabolizable energy value of cassava meal (70\% starch) is equivalent to that of maize. Furthermore, cassava root is essentially a major carbohydrate source (20-31 percent). It is rich in calcium and vitamin c, amylopectin (70\%), amylase (20\%) and also contains a nutritionally significant quality of thiamine, riboflavin and nicotinic acid (Tewe, 2004). If well processed, cassava anti-nutritional factors can be reduced to tolerable limits. It is therefore imperative to properly exploit cassava's nutritive potential, availability, increasing production of improved breeds and cheapness as a dietary resource for poultry. This becomes necessary because of the un-abated increase in the price of grain such as maize, sorghum and millet coupled with the unending competition for human, livestock and industrial use. This study, therefore, evaluated the effects of substituting maize with cassava root meal ("Garri") on the growth performance, economic efficiency, carcass and organ characteristics, hematology andserum chemistry of broiler chickens in a warm humid tropical environment.

\section{Materials and Methods}

Experimental Site: This study was carried out at the Poultry Unit of the Teaching and Research Farm of Michael Okpara University of Agriculture, Umudike; located on latitude $05^{0}, 29^{\circ}$ north and latitude $07^{0}, 21^{0}$ east of the rain forest zone of the south-eastern part of Nigeria. The climate of the region is characterized by a mean 
daily temperature of between $27^{\circ} \mathrm{C}$ and $35^{\circ} \mathrm{C}$, all through the year. The average rainfall is about $2000 \mathrm{~mm}$ per annum with a double maxima pattern.

Processing of text materials: The cassava root was peeled, washed, grated (using mechanized grater) and packed into bags. The bags were pressed to drain effluent from the grated cassava pulp, and then left to ferment for 3 days, while exposed to natural elements. After 3 days, the meal was sieved and then fried in shallow potsplaced over fire for about 20-25minutes (having less than 5\% moisture). The final product is known and called "garri" in Nigeria.

Experimental Diets: Eleven (11) treatment diets were formulated (table1). Diet 1 represents the control diet, with $58.60 \%$ yellow maize as the major energy source, while diets 2 to 11 had their maize substituted with cassava root meal "Garri" at increasing graduated levels of $10 \%$ up to $100 \%$. The calculated protein and energy content of the diets respectively ranged from $20.70-24.22 \%$ and $2914.54-3207.54 \mathrm{kcal} / \mathrm{kg}$. The diets were sufficiently furnished with synthetic methionine and lysine to mitigate the effect of low protein content of the test ingredient (cassava root meal -"garri"). These diets were fed to birds for a period of 56 days.

Experimental birds, management procedure, statistical design and data collection:Two hundred and twenty day-old Anak unsexed broiler chicks purchased from a reputable hatchery were randomly allocated to the (11) dietary treatments in a Completely Randomized Design Experiment. 20 chicks were allocated to each of the treatment diets having 2 replicates with 10 birds per replicate. The birds were weighted in group of tens at the beginning of trial and individually weekly thereafter. Feed and water were given adlibitum, while all routine health management procedures were followed religiously.

Data on Feed intake and weight changes were collected. Feed-to-gain ratio was calculated, while carcass and organ portions were evaluated according to the procedures of Scott et al. (1969)and Ojewola and Longe (2000). Serum chemistry and Hematology evaluations were carried out using each or combinations of internationally acceptable Standard procedures (Lewis and Ward, 1975; Dacie and Lewis, 1984; and IFCC 1986Okeudo et al. 2003 Ganong, 2011). Economics of production of the broiler chickens produced were also evaluated. All the data obtained were subjected to Analysis of Variance (ANOVA) in a Completely Randomized Design (CRD). Differences observed among the treatment means were separated using Duncan's Multiple Range Test (Duncan, 1995 and Steel and Torrie, 1980).

\section{Results and Discussion}

The result of the performance characteristics evaluation (Table 2) revealed that birds fed diets 1 and 2 were significantly $(\mathrm{P}<0.05)$ superior $(3045.25 \mathrm{~g} ; 2795.0 \mathrm{~g})$ to the others. The mean weight of the birds on the remaining diets (3-11) were slightly depressed, numerically but were comparable. It ranged from 1995.07g (Diet 5) to $2394.95 \mathrm{~g}$ (Diet 3). This could be due to the superiority of maize over the cassava root meal. Maize is known to be richer in protein, energy and most of the essential minerals and vitamins (Pfizer, 1995) coupled with the adequacy of the nutrient profile of diets 1 and 2 as presented in the calculated analysis of the diets (Table 2).

The mean total feed intake was significantly $(\mathrm{P}<0.05)$ influenced, followed no specific pattern, but ranged from 5172.0g (Diet 1) to 5675.0g (Diet 3). The feed-to-gain ratio was also better for birds on Diets 1(1.70) and 2(1.99). The generally high feed intake values obtained are proofs that the diets were relished by the birds, adequate for body maintenance, growth and productive purposes within the environment in which the trial was conducted. Akinmutimi (2004) also observed that feed intake could be enhanced when anti-nutritional factors are reduced to tolerable level through efficient processing of text ingredients, as was done in this trial. Cassava root meal, though a poor source of protein is rich in calcium and vitamin C, amylopectin (70\%), Amylose (20\%), digestibility of over $75 \%$ and contain a nutritionally significant quality of thiamine, riboflavin and nicotinic acid (Tewe, 2004) which could have contributed positively to the generally good performance of birds fed the graded levels of cassava. Tables 3 and 4 show the carcass characteristics (g and \%) of broiler chickens fed varying levels of cassava root meal as substitute for maize.

The yield and quantity of poultry meat can be improved by the application of appropriate knowledge in the utilization of arrays of conventional and unconventional dietary energy and protein sources in the humid tropics. The mean weights of the birds ranged from 2050g (D5) to 3100(D1), while the mean dressed weight ranged from $1425 \mathrm{~g}$ (D6 and 7) to $2272.50 \mathrm{~g}$ (D1).

The percent dressed weights were also significantly $(\mathrm{P}<0.05)$ influenced, with the highest and least values being respectively $73.33 \%$ and $60.60 \%$ for birds fed diets 1 and 6 . The cut-parts (thigh, wings and drumsticks) showed significant difference $(\mathrm{P}<0.05)$ while that of back-cut and breast were not. Generally, no definite trend was observed in the dressed weights and cut-part values. Nonetheless, the values obtained are 
comparable to those reported by Ojewola (2000). Productive performance, carcass yield and cut-parts are products of many complex nutritional and environmental interactions, but weight, volumes and dimension of broiler parts are directly related to the carcass weights, which were not less than $2 \mathrm{~kg}$ at the end of this trial. An indication that the increasing dietary metabolizable energy obtained as the levels of cassava root meal substitution for maize increased, enhanced growth weight gains and final weight.

Table 5 shows the organ proportion of broiler chickens fed varying levels of cassava root meal.

Of all the parameters considered, gizzard, liver, spleen, proventriculus, heart and lungs showed significant difference $(\mathrm{P}<0.05)$, while kidney, bile and crop were not. No definite trend traceable to the diets was observed. The size of liver, kidney and heart were within the range of values regarded as normal, which according to Ewuolaet al. (2003) and Aderemi (2003) is an indication of none severe toxicity of toxins and or anti-nutrients in the diet administered to the birds during the trial.

Tables 6 and 7 showed the results of the Hematology and serum chemistry of the broiler chickens fed graded levels of cassava root meal as a substitute for maize.

All the variables investigated under the hematology evaluation differed significantly $(\mathrm{P}<0.05)$ among the birds fed the experimental diet, only with the exception of PCV and HBC. The serum biochemical parameters were significantly $(\mathrm{P}<0.05)$ influenced, except ALP $($ Valid $\mathrm{N})$ which was not.

Most of the hematology variables/values all within the range reported for healthy birds (Adeyemo and Sanni, 2013). So are the serum variables, which showed that there was no intense detoxification of any antinutrient and or toxic material by the liver and or spleen. There was also no evidence of injury or increased serum amino-transferase activity (Vroom and Israeli, 1990). A confirmation of the fact that grating, pressing, drying, fermentation of cassava root meal for three days and frying reduced or eliminated cyanogenicglucosides (Linamarin and Lotaustralin) and other anti-nutrients, thus making cassava root meal a veritable dietary energy source for poultry.

Table 8 shows the cost implication of feeding broiler diet containing varying levels of cassava root meal("Garri") as replacement for maize. The result shows that all the variables considered were significantly $(\mathrm{P}<0.05)$ influenced by the diet. There was a corresponding increase in the cost $/ \mathrm{Kg}$ feed $(\mathrm{N})$ and cost $/$ total feed consumed as the level of maize substitution for cassava root meal increased from 0-100\% (Diets 1-11).This in turn led to an increase in the cost/Kg weight gain of the birds, with a corresponding decrease in both the realizable revenue ( $\mathrm{N} / \mathrm{bird}$ ) and gross margin. Though, economically profitable feeding of poultry is an issue of great importance, coupled with the usage of unconventional but highly available dietary nutrient source. The cost of rearing broiler chicken with cassava root meal might have depressed revenue, but it cannot be said to be unprofitable even with least revenue ( $\$ 505 /$ bird) and gross margin (\$689.48) obtained in this trial.

\section{Conclusion:}

Based on the results obtained in this study, Cassava root holds a great promise in the production of broiler chicken in the warm humid tropical environment. At 56 days, all the experimental diets yielded broiler chickens with weights (final/gain) that are higher than $2 \mathrm{~kg}$. The dressed yield and carcass cut-parts also showed a direct relationship with the carcass weights. The organ proportions, serum chemistry and hematological variables were not negatively affected by the increasing substitution levels of well processed cassava root meal for maize. The superiority of maize as a dietary energy was confirmed; the cost of rearing broiler chicken with cassava root meal was also found to have depressed revenue but it cannot be said to be unprofitable. Therefore, well processed cassava root meal "garri" is highly recommended for broiler production wherever it is highly available and cheaper than maize.

\section{Reference}

[1] Aderemi,F.A. 2003: Effect of enzyme supplemented cassava root siviet in cassava based diet on some visceral organs of pullet chicks. Proc. $8^{\text {th }}$ Annual Conference of the Animal Science Association of Nigeria.April 17-24.pp?

[2] Adekanye, T.O; Ogunjimi, S.I; Ajala, A.O. (21 April, 2013). An assessment of cassava processing plants in Irepodun Local Government Areas, Kwara State, Nigeria.Wolrd Journal of Agricultural Research 1(1) 14-17. Retrieved 22 September, 2013.

[3] Adeyemo,I.A. and Sanni, A. 2013. Hematological parameters and serum Biochemical Indices of Broiler chickens fed aspergillusnigerhydrolysed cassava peel meal-Based diet. IJRRAS 15(3):410-415.

[4] Akinmutimi.A.H 2004.Evaluation of sword bean(canavaliagladiata) as an alternative feed resource for broiler chickens.Ph.D. dissertation, Michael Okpara University of Agriculture, Umudike; Abia State. Nigeria.

[5] Dacie,J.N and Lewis. S.M.1984: PracticalHematology. $8^{\text {th }}$ Edition.Edinburgh;Churchill Livingstone.Pg1-6.

[6] Duncan, D.B. 1955. Multiple Range and Multiple F-test Biometric.11.1-24.

[7] Ewuola,E.O; Ogunlade,J.T;Gbore, F.A; Salako, A.O; Idahor, K.O and Egbunike,G.N.(2003): Performance and evaluation and organ histology of rabbits fed fusoriumvetticilliodes culture materials. Tropical Animal Investments,6:11-11.

[8] FAO/FAOSTAT: Production, Crops, and Cassava, 2010 data: Food and Agriculture Organization.2011. Jump up.

[9] Ganong,W.F 2011.Review of Medical Physiology.California Lange Medical Publishers.Pp. 56-65; 381-420,577-578.

[10] IFCC(1986).Methods for the measurement of catalytic concentrations of enzymes.International Federation of Clinical Chemistry and Laboratory Medicine. Journal of Clinical Chemistry and Biochemistry, 24: 481-495.

[11] ILCA(International Livestock Center for Africa) 1980: Livestock production in Africa-the Challenge. Pp.7-14 in ILCA: the first Year Addis Ababa, Ethiopia. 
Biologic and Economic Performance of Broiler Chickens Fed Cassava Root Meal "Garri” as a...

[12] Ojewola,G.S and Longe, O.G.(1999): Protein and Energy in Broiler starter diets: Effects on Growth performance and Nutrient Utilization. Nig.J. Anim. Prod.26 (1)23-27.

[13] Ojowola, G.S and Longe, O.G. (2000): Carcass yield and Quality of Broiler Chicken fed varying protein levels.Global Journal of pure and applied Sciences.vol.6.No. 3.407-411.

[14] Oke, O.L. 1978: Problems in the use of cassava as animal feed. Animal feed science and Technology.3:345-380

[15] Okeudo, N, Okoli, I.C and Igwe G.O.F.(2003): Heamatological characteristics of ducks, CarmiaMochatia of South Eastern Nigeria.Tropicuttria 21:61-65.

[16] Tewe.O.O.2004: The Global Cassava Development Strategy: Cassava for livestock feed in Sub-Sahara Africa.ICAD and FAO. Jump up.

[17] Pfizer Nutrient Master Plan (PNMP) 1995: Tropical Crops dicotyledons. Longman Ltd, London 1 ${ }^{\mathrm{st}}$ Ed. Pp. 242-245.

[18] Sauvant, D; Perez, J.M; Tran.G.2004. Tables INRA-AFZ decomposition et de valeurnutritine des matieres premieres destinees aux animauxd'elevage: 2eme edition. ISBN2738011586, 306p.INRA Edition Versailles.

[19] Scott, M.L Nesheim, M.C and Young, R.J. 1969: Nutrition of the chicken (M.L. Scott and Associates,Ithaca, New York, P.511.

[20] Steel, R.G and Torie, J. H.1980: Principles and Procedure of statistics. A Biometrical Approach (2 ${ }^{\text {nd }}$ Edition).McGrawHill,Tokyo.Pp.688.

[21] Vroon, D.H. and Israili, Z.1990: Aminotransferases. In: Walker, H.K; Hall, W.D., Hurst,J.W., (eds):Clinical methods: The History, Physical, and Laboratory Examinations. $3^{\text {rd }}$ edition. Boston: Butterworths; chapter 99.

Table 1: Percent Composition of Broiler diets containing varying levels of cassava meal as Replacement for Maize.

\begin{tabular}{|c|c|c|c|c|c|c|c|c|c|c|c|}
\hline & $\mathrm{Dl}$ & D2 & D3 & D4 & D5 & D6 & D7 & D8 & D9 & Dl0 & D11 \\
\hline Maize (Yellow) & 58.60 & 52.74 & 46.88 & 41.02 & 35.16 & 29.30 & 23.44 & 17.58 & 11.72 & 5.86 & - \\
\hline FermentedCassava Root meal (Gami) & - & 5.86 & 11.72 & 17.58 & 23.44 & 29.30 & 35.16 & 41.02 & 46.88 & 52.74 & 58.60 \\
\hline Soyabean meal & 32.00 & 32.00 & 32.00 & 32.00 & 32.00 & 32.00 & 32.00 & 32.00 & 32.00 & 32.00 & 32.00 \\
\hline Fishmeal $(72 \%)$ & 5.50 & 5.50 & 5.50 & 5.50 & 5.50 & 5.50 & 5.50 & 5.50 & 5.50 & 5.50 & 5.50 \\
\hline Bone meal & 2.00 & 2.00 & 2.00 & 2.00 & 2.00 & 2.00 & 2.00 & 2.00 & 2.00 & 2.00 & 2.00 \\
\hline Oyster shell & 1.00 & 1.00 & 1.00 & 1.00 & 1.00 & 1.00 & 1.00 & 1.00 & 1.00 & 1.00 & 1.00 \\
\hline Salt & 0.25 & 0.25 & 0.25 & 0.25 & 0.25 & 0.25 & 0.25 & 0.25 & 0.25 & 0.25 & 0.25 \\
\hline Vitamin-mineral Premix * & 0.25 & 0.25 & 0.25 & 0.25 & 0.25 & 0.25 & 0.25 & 0.25 & 0.25 & 0.25 & 0.25 \\
\hline Methionine & 0.20 & 0.20 & 0.20 & 0.20 & 0.20 & 0.20 & 0.20 & 0.20 & 0.20 & 0.20 & 0.20 \\
\hline Lysine & 0.20 & 0.20 & 0.20 & 0.20 & 0.20 & 0.20 & 0.20 & 0.20 & 0.20 & 0.20 & 0.20 \\
\hline Total & 100.00 & 100.00 & 100.00 & 100.00 & 100.00 & 100.00 & 100.00 & 100.00 & 100.00 & 100.00 & 100.00 \\
\hline
\end{tabular}

Calculated analysis:

Metabolizeable Energy, kcalkg

Crude Protein (\%).

Calorie ratio: Protein

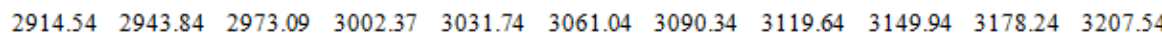

$\begin{array}{lllllllllll}24.22 & 23.87 & 23.52 & 23.17 & 22.81 & 22.46 & 22.11 & 21.76 & 21.41 & 21.06 & 20.70\end{array}$

Crude fibre

$\begin{array}{lllllllllll}120.34 & 123.33 & 126.41 & 129.58 & 134.68 & 136.29 & 139.77 & 143.37 & 147.12 & 150.91 & 154.95\end{array}$

Methionine

$\begin{array}{lllllllllll}3.40 & 3.62 & 3.75 & 3.95 & 4.11 & 4.28 & 4.44 & 4.60 & 4.77 & 4.932 & 5.10\end{array}$

Lysine

$\begin{array}{lllllllllll}0.61 & 0.42 & 0.41 & 0.41 & 0.40 & 0.39 & 0.38 & 0.37 & 0.37 & 0.37 & 0.36\end{array}$

Composition of 2.5kg (Bio-mix) Premix: Vit A. (500,000 IU), Vit D3 (100,000 IU), Vit. E (2,000mg), Vit. K3 (100mg), Vit.B1 (120mg), Vit.B2 (240mg), Niacin (1,600mg), Calcium pantothenate (400mg), Biotin (3.3mg), Vit. B12 (1.0mg), Folicacid (40mg), Choline chloride (12,000mg), Mn (4000mg), Iron (2000mg), Zinc (1,800mg), Copper (80mg), Iodine (61mg), Selenium (4mg), Growth promoter (1,600mg), Antioxidant (8,000mg).

Table 2: Performance Characteristics of Broiler Chickens fed varying levels of Cassava root meal as Replacement for Maize.

\begin{tabular}{|c|c|c|c|c|c|c|c|c|c|c|c|c|}
\hline Parameter & T $\times 1$ & $T \times 2$ & $\mathrm{~T} \times 3$ & $\mathrm{~T} \times 4$ & T $\times 5$ & T $\times 6$ & T $\times 7$ & T $\times 8$ & T $\times 9$ & $\mathrm{~T} \times 10$ & $T \times 11$ & SEM \\
\hline Initial Weight (g) & 54.75 & 55.05 & 55.05 & 54.90 & 54.94 & 54.85 & 55.15 & 54.64 & 55.15 & 55.16 & 55.00 & 0.0594 \\
\hline Final Weight (g) & $3100.00^{b}$ & $2850.00^{b}$ & $2450.00^{\mathrm{a}}$ & $2250.00 \mathrm{p}^{2}$ & $2050.00^{\mathrm{a}}$ & $2350.00^{\mathrm{a}}$ & $2250.00^{\mathrm{a}}$ & $2300.00^{\mathrm{a}}$ & $2350.00^{2}$ & $2200.00^{\mathrm{a}}$ & $2150.00^{\mathrm{a}}$ & 70.5296 \\
\hline Weight gain (g) & $3045.25^{b}$ & $2795.00^{\mathrm{b}}$ & $2394.95^{\mathrm{a}}$ & $2195.10^{\mathrm{a}}$ & $1995.07^{\mathrm{a}}$ & $2295.15^{\mathrm{a}}$ & $2194.85^{\mathrm{a}}$ & $2244.92^{\mathrm{a}}$ & $2294.85^{\mathrm{a}}$ & $2144.85^{a}$ & $2095.00^{\mathrm{a}}$ & 70.5416 \\
\hline Total Feed Intake (g) & $5172.00^{\text {st }}$ & $5538.00^{\text {sb }}$ & $5675.00^{b}$ & $5633.00^{\mathrm{ab}}$ & $5609.50^{\text {tb }}$ & $5461.00^{\text {tb }}$ & $5715.50^{b}$ & $5392.50^{\text {tb }}$ & $5397.50^{\text {tb }}$ & $5354.50^{\text {tb }}$ & $5087.50^{2}$ & 56.6111 \\
\hline Daily Feed Intake (g) & $92.36^{\mathrm{ab}}$ & $98.90^{2 \mathrm{~b}}$ & $101.59^{\mathrm{b}}$ & $100.59^{\mathrm{ab}}$ & $100.17^{2 b}$ & $97.52^{\mathrm{ab}}$ & $102.07^{\mathrm{b}}$ & $94.57^{\mathrm{ab}}$ & $96.39^{2 \mathrm{~b}}$ & $95.62^{\mathrm{ab}}$ & $90.85^{\mathrm{a}}$ & 1.0110 \\
\hline Feed-to-Gain Ratio & $1.70^{2}$ & $1.99^{\mathrm{a}}$ & $2.38^{6}$ & $2.92^{\mathrm{d}}$ & $2.82^{\mathrm{cd}}$ & $2.56^{\mathrm{bc}}$ & $2.56^{\mathrm{bc}}$ & $2.36^{b}$ & $2.35^{b}$ & $2.52^{\mathrm{bc}}$ & $2.62^{\text {bed }}$ & 0.0759 \\
\hline
\end{tabular}

a - d: Means in the same row with different superscripts are significantly different from one another $(\mathbf{P}<0.05)$ 
Biologic and Economic Performance of Broiler Chickens Fed Cassava Root Meal "Garri” as a...

Table 3: Carcass Characteristics (g) of Broiler Chickens Fed Graded levels of Cassava Root Mealas

Replacement for Maize.

\begin{tabular}{|c|c|c|c|c|c|c|c|c|c|c|c|c|}
\hline Parameters $(96)$ & Txl & $\mathrm{T} \times 2$ & $\mathrm{~T} \times 3$ & $\mathrm{~T} \times 4$ & T $\times 5$ & T×6 & T $\times 7$ & Tx 8 & T×9 & $\mathrm{T} \times 10$ & Txll & (SEM) \\
\hline Live weight & $3100.00^{2}$ & $2850.00^{b}$ & $2450.00^{2}$ & $2250.00^{2}$ & $2050.00^{2}$ & $2350.00^{2}$ & $2250.00^{2}$ & $2300.00^{2}$ & $2350.00^{2}$ & $2200.00^{2}$ & $2150.00^{2}$ & 70.5296 \\
\hline Defeatheredwt & $2888.00^{6}$ & $2550.00^{\circ}$ & $2350.00^{\mathrm{be}}$ & $2000.00^{2 b}$ & $1950.00^{2}$ & $1975.00^{2 b}$ & $1950.00^{\mathrm{a}}$ & $2175.00^{\mathrm{sbc}}$ & $2225.00^{\mathrm{sbc}}$ & $2075.00^{2 b}$ & $2050.00^{2 b}$ & 66.3219 \\
\hline Dressed weight & $2272.50^{\circ}$ & $1950.00^{\mathrm{be}}$ & $1775.00^{\mathrm{ab}}$ & 1545.00 & $1450.00^{2}$ & $1425.00^{2}$ & $1425.00^{2}$ & $1675.00^{2 b}$ & $1575.00^{2}$ & $1500.00^{2}$ & $1475.00^{2}$ & 60.2325 \\
\hline Thigh & $350.00^{8}$ & $300.00^{\mathrm{sbc}}$ & $325.00^{\mathrm{bc}}$ & $225.00^{\mathrm{ab}}$ & $200.00^{2}$ & $200.00^{2}$ & $225.00^{25 b}$ & $275.00^{\mathrm{sbc}}$ & $275.00^{\mathrm{abc}}$ & $250.00^{6 \mathrm{c}}$ & $250.00^{\mathrm{sc}}$ & 12.2791 \\
\hline Back-cut & $575.00^{\circ}$ & $375.00^{2}$ & $375.00^{2}$ & $300.00^{2}$ & $300.00^{2}$ & $250.00^{2}$ & $300.00^{2}$ & $325.00^{\circ}$ & $300.00^{2}$ & $300.00^{2}$ & $300.00^{2}$ & 21.1114 \\
\hline Breast & $650.00^{b}$ & $650.00^{\mathrm{b}}$ & $525.00 \mathrm{ab}$ & $450.00^{2}$ & $475.00^{\mathrm{ab}}$ & $375.00^{2}$ & $420.00^{2}$ & $550.00^{2 b}$ & $525.00^{\mathrm{ab}}$ & $500.00^{2 \mathrm{~b}}$ & $475.00^{2 \mathrm{bb}}$ & 215452 \\
\hline Neck & $70.50^{2}$ & $164.50^{\circ}$ & $115.00^{2 b}$ & $101.50^{\mathrm{ab}}$ & $104.00^{26}$ & $105.50^{\mathrm{ab}}$ & $118.50^{2 \mathrm{bb}}$ & $103.00^{2 b}$ & $116.50^{\mathrm{sb}}$ & $102.50^{\mathrm{sb}}$ & $85.00^{2}$ & 6.5658 \\
\hline Wings & $265.00^{\circ}$ & $225.00^{\mathrm{bc}}$ & $225.00^{\mathrm{bc}}$ & $200.00^{\mathrm{b}}$ & $150.00^{2}$ & $200.00^{\circ}$ & $200.00^{\circ}$ & $200.00^{\mathrm{b}}$ & $225.00^{\mathrm{bc}}$ & $200.00^{6}$ & $200.00^{\circ}$ & 6.5675 \\
\hline Drumstick & $350.00^{\mathrm{b}}$ & $275.00^{\mathrm{ab}}$ & $275.00^{\mathrm{ab}}$ & $275.00^{26}$ & $200.00^{2}$ & $225.00^{\mathrm{a}}$ & $225.00^{\mathrm{a}}$ & $205.00^{\mathrm{a}}$ & $250.00^{\mathrm{a}}$ & $225.00^{\mathrm{a}}$ & $200.00^{2}$ & 10.7844 \\
\hline
\end{tabular}

a - d: Means in the same row with different superscripts are significantly different from one another $(\mathbf{P}<\mathbf{0 . 0 5})$

Table 4: Carcass Characteristics (\%) of Broiler Chickens fed Varying levels of Cassava root meal as Replacement for Maize.

\begin{tabular}{|c|c|c|c|c|c|c|c|c|c|c|c|c|}
\hline Parameters (\%) & $T \times 1$ & $T \times 2$ & $T \times 3$ & $T \times 4$ & $T \times 5$ & $T \times 6$ & $T \times 7$ & $T \times 8$ & $T \times 9$ & $T \times 10$ & $\mathrm{~T} \times 11$ & (SEM) \\
\hline Defeatheredwt & $93.25^{\mathrm{bc}}$ & $89.48^{\mathrm{abc}}$ & $95.90^{\circ}$ & $89.50^{\mathrm{ab}}$ & $95.00^{\circ}$ & $83.97^{\mathrm{a}}$ & $86.66^{\mathrm{ab}}$ & $94.57^{c}$ & $94.66^{c}$ & $94.17^{c}$ & $95.33^{c}$ & 0.9518 \\
\hline Dressed weight & $73.33^{c}$ & $68.42^{\mathrm{abc}}$ & $72.41^{c}$ & $68.25^{\mathrm{ab}}$ & $70.72^{b c}$ & $60.60^{\mathrm{a}}$ & $63.25^{\mathrm{ab}}$ & $72.83^{c}$ & $66.99^{\mathrm{ab}}$ & $67.92^{\mathrm{ab}}$ & $68.37^{\mathrm{ab}}$ & 0.9742 \\
\hline Thigh & $15.43^{\mathrm{ab}}$ & $15.40^{\mathrm{ab}}$ & $18.30^{\circ}$ & $14.71^{\mathrm{ab}}$ & $13.81^{\mathrm{a}}$ & $13.89^{\mathrm{a}}$ & $15.76^{\mathrm{ab}}$ & $16.45^{\mathrm{ab}}$ & $17.42^{\mathrm{ab}}$ & $16.52^{\mathrm{ab}}$ & $16.78^{\mathrm{ab}}$ & 0.3948 \\
\hline Back-cut & 25.23 & 19.28 & 20.93 & 19.72 & 20.72 & 17.22 & 21.22 & 19.43 & 19.09 & 19.91 & 20.22 & 0.6695 \\
\hline Breast & 28.77 & 33.36 & 29.63 & 29.58 & 32.86 & 25.93 & 29.57 & 32.80 & 33.33 & 33.49 & 32.46 & 0.8597 \\
\hline Wings & $11.69^{\mathrm{ab}}$ & $11.51^{\mathrm{ab}}$ & $12.64^{\mathrm{ab}}$ & $13.15^{\mathrm{ab}}$ & $10.36^{\mathrm{a}}$ & $14.07^{b}$ & $14.14^{b}$ & $11.94^{\mathrm{ab}}$ & $14.24^{b}$ & $13.75^{\mathrm{ab}}$ & $13.75^{\mathrm{ab}}$ & 0.3510 \\
\hline Drumstick & 15.35 & 14.08 & 15.47 & 18.16 & 13.81 & 15.74 & 16.07 & 12.25 & 15.91 & 15.50 & 13.75 & 0.5230 \\
\hline
\end{tabular}

a - d: Means in the same row with different superscripts are significantly different from one another $(\mathbf{P}<\mathbf{0 . 0 5})$

Table 5a: Organ Characteristics/Proportion (g) of Broiler Chickens Fed Graded Levels of Cassava Root Mealas Replacement for Maize.

\begin{tabular}{|c|c|c|c|c|c|c|c|c|c|c|c|c|}
\hline Parameters & $T \times 1$ & $T \times 2$ & $T \times 3$ & $T \times 4$ & $T \times 5$ & $T \times 6$ & $T \times 7$ & $T \times 8$ & $T \times 9$ & $T \times 10$ & $T \times 11$ & (SEM) \\
\hline Gizzard & $1.45^{\mathrm{ab}}$ & $1.76^{\mathrm{ab}}$ & $1.58^{\mathrm{ab}}$ & $1.79^{\mathrm{ab}}$ & $2.05^{b}$ & $1.72^{\mathrm{ab}}$ & $1.62^{\mathrm{ab}}$ & $1.46^{\mathrm{ab}}$ & $1.24^{\mathrm{a}}$ & $1.49^{\mathrm{ab}}$ & $1.40^{\mathrm{ab}}$ & 0.0611 \\
\hline Liver & $1.93^{\mathrm{ab}}$ & $2.14^{a b}$ & $1.82^{\mathrm{ab}}$ & $1.71^{\mathrm{ab}}$ & $1.78^{\mathrm{ab}}$ & $1.73^{\mathrm{ab}}$ & $1.12^{\mathrm{a}}$ & $1.61^{\mathrm{ab}}$ & $2.50^{\mathrm{b}}$ & $2.41^{b}$ & $2.30^{\mathrm{b}}$ & 0.1071 \\
\hline Spleen & $0.08^{\mathrm{ab}}$ & $0.07^{\mathrm{ab}}$ & $0.09^{\mathrm{ab}}$ & $0.07^{\mathrm{ab}}$ & $0.12^{\mathrm{ab}}$ & $0.09^{\mathrm{ab}}$ & $0.09^{\mathrm{ab}}$ & $0.13^{b}$ & $0.13^{b}$ & $0.04^{\mathrm{a}}$ & $0.14^{b}$ & 0.0084 \\
\hline Kidney & 0.43 & 0.46 & 0.53 & 044 & 0.54 & 0.51 & 0.51 & 0.57 & 0.52 & 0.58 & 0.56 & 0.0183 \\
\hline Bile & 0.07 & 0.13 & 0.08 & 0.050 & 0.05 & 0.04 & 0.05 & 0.04 & 0.06 & 0.05 & 0.05 & 0.0082 \\
\hline Proventinculus & $0.28^{\mathrm{ab}}$ & $0.27^{\mathrm{a}}$ & $0.35^{\mathrm{ab}}$ & $0.32^{\mathrm{ab}}$ & $0.40^{\mathrm{b}}$ & $0.24^{\mathrm{a}}$ & $0.25^{\mathrm{a}}$ & $0.28^{\mathrm{ab}}$ & $0.33^{\mathrm{ab}}$ & $0.25^{\mathrm{a}}$ & $0.26^{\mathrm{a}}$ & 0.0132 \\
\hline Intestine & 2.55 & 3.38 & 3.21 & 3.91 & 3.32 & 4.49 & 4.90 & 3.15 & 3.93 & 5.41 & 3.58 & 0.3812 \\
\hline Heart & $0.38^{\mathrm{ab}}$ & $0.35^{\mathrm{ab}}$ & $0.37^{\mathrm{ab}}$ & $0.32^{\mathrm{a}}$ & $0.49^{\mathrm{ab}}$ & $0.32^{\mathrm{a}}$ & $0.31^{\mathrm{a}}$ & $0.37^{\mathrm{ab}}$ & $0.52^{b}$ & $0.41^{\mathrm{ab}}$ & $0.35^{\mathrm{ab}}$ & 0.0189 \\
\hline Crop & 0.36 & 0.42 & 0.45 & 0.55 & 0.51 & 0.43 & 0.54 & 0.44 & 0.64 & 0.51 & 0.42 & 0.0275 \\
\hline Lungs & $0.36^{\mathrm{a}}$ & $0.37^{\mathrm{a}}$ & $0.45^{\mathrm{abc}}$ & $0.54^{b c}$ & $0.47^{\mathrm{abc}}$ & & $0.47^{\mathrm{abc}}$ & $0.44^{\mathrm{a} b c}$ & $0.41^{\mathrm{ab}}$ & $0.48^{\mathrm{abc}}$ & $0.58^{c}$ & 0.0163 \\
\hline
\end{tabular}

a - d: Means in the same row with different superscripts are significantly different from one another $(\mathbf{P}<\mathbf{0 . 0 5})$ 
Biologic and Economic Performance of Broiler Chickens Fed Cassava Root Meal "Garri" as a...

Table 5b: Organ Characteristics of Broiler Chickens Fed Graded Levels of Cassava Root Meal as Replacement for Maize.

\begin{tabular}{|c|c|c|c|c|c|c|c|c|c|c|c|c|}
\hline Parameters & $T \times 1$ & $T \times 2$ & $T \times 3$ & $T \times 4$ & $T \times 5$ & $T \times 6$ & $T \times 7$ & $T \times 8$ & $T \times 9$ & $T \times 10$ & $T \times 11$ & (SEM) \\
\hline Gizzard & $44.50^{\mathrm{bc}}$ & $50.00^{c}$ & $38.50^{\mathrm{abc}}$ & $40.00^{\mathrm{abc}}$ & $42.00^{\mathrm{abc}}$ & $40.50^{\mathrm{abc}}$ & $36.50^{\mathrm{abc}}$ & $33.50^{\mathrm{ab}}$ & $28.50^{\mathrm{3}}$ & $32.00^{\mathrm{ab}}$ & $30.50^{\mathrm{ab}}$ & 1.6268 \\
\hline Liver & $59.00^{c}$ & $61.00^{c}$ & $44.50^{\mathrm{ab}}$ & $38.50^{\mathrm{ab}}$ & $36.50^{\mathrm{ab}}$ & $40.50^{\mathrm{ab}}$ & $25.00^{\mathrm{a}}$ & $37.00^{\mathrm{ab}}$ & $57.50^{c}$ & $53.50^{\mathrm{ab}}$ & $49.50^{\mathrm{sb}}$ & 3.0218 \\
\hline Spleen & 2.50 & 2.00 & 2.00 & 1.50 & 2.50 & 2.00 & 2.00 & 3.00 & 3.00 & 1.50 & 2.50 & 0.1461 \\
\hline Kidney & 13.00 & 13.00 & 13.00 & 10.00 & 11.00 & 12.00 & 11.50 & 13.80 & 12.00 & 13.00 & 12.00 & 0.4893 \\
\hline Bile & 2.00 & 3.50 & 1.00 & 2.00 & 1.00 & 1.00 & 1.00 & 1.00 & 1.35 & 1.00 & 1.00 & 0.2427 \\
\hline Proventriculus & 8.50 & 7.50 & 8.50 & 7.00 & 8.00 & 5.00 & 5.00 & 6.00 & 7.50 & 5.00 & 5.00 & 0.3243 \\
\hline Intestine & 78.00 & 96.50 & 78.00 & 89.50 & 68.50 & 105.00 & 109.00 & 72.50 & 147.00 & 114.50 & 76.50 & 7.5149 \\
\hline Heart & 11.50 & 10.00 & 9.00 & 7.00 & 10.00 & 7.50 & 7.00 & 8.50 & 12.00 & 9.00 & 7.50 & 0.4790 \\
\hline Crop & 11.00 & 12.00 & 11.00 & 12.50 & 10.00 & 10.00 & 12.00 & 10.00 & 14.00 & 11.00 & 9.0 & 0.5981 \\
\hline Lungs & 11.00 & 10.50 & 11.00 & 12.00 & 9.50 & 11.00 & 10.50 & 9.50 & 9.50 & 10.50 & 12.50 & 0.3379 \\
\hline
\end{tabular}

a - d: Means in the same row with different superscripts are significantly different from one another $(\mathbf{P}<\mathbf{0 . 0 5})$

Table 6: Hematology of Broiler Chickens Fed Varying Levels of Cassava Root Meal as Replacement for Maize.

\begin{tabular}{lllllllllllll}
\hline Parameters & $\mathbf{T} \times 1$ & $\mathbf{T} \times 2$ & $\mathbf{T} \times \mathbf{3}$ & $\mathbf{T} \times \mathbf{4}$ & $\mathbf{T} \times \mathbf{5}$ & $\mathbf{T} \times \mathbf{6}$ & $\mathbf{T} \times \mathbf{7}$ & $\mathbf{T} \times \mathbf{8}$ & $\mathbf{T} \times \mathbf{9}$ & $\mathbf{T} \times \mathbf{1 0}$ & $\mathbf{T} \times \mathbf{1 1}$ & (SEM) \\
\hline PCV & $30.25^{\mathrm{ab}}$ & $30.25^{\mathrm{b}}$ & $28.25^{\mathrm{ab}}$ & $27.00^{\mathrm{ab}}$ & $27.75^{\mathrm{ab}}$ & $32.50^{\mathrm{c}}$ & $27.25^{\mathrm{ab}}$ & $27.50^{\mathrm{ab}}$ & $25.75^{\mathrm{ab}}$ & $23.75^{\mathrm{a}}$ & $24.00^{\mathrm{a}}$ & 0.7089 \\
HBConcn & $7.35^{\mathrm{ab}}$ & $7.19^{\mathrm{ab}}$ & $6.32^{\mathrm{ab}}$ & $6.38^{\mathrm{ab}}$ & $6.49^{\mathrm{ab}}$ & $7.93^{\mathrm{c}}$ & $6.27^{\mathrm{ab}}$ & $7.16^{\mathrm{ab}}$ & $6.23^{\mathrm{ab}}$ & $6.13^{\mathrm{ab}}$ & $5.56^{\mathrm{a}}$ & 0.1938 \\
RBCounts. & 2.27 & 2.20 & 2.02 & 1.82 & 2.33 & 2.61 & 1.76 & 2.16 & 1.84 & 1.79 & 1.76 & 0.0833 \\
MCV & 134.35 & 138.04 & 157.02 & 148.77 & 122.45 & 126.46 & 155.24 & 127.10 & 140.81 & 134.21 & 136.31 & 5.0814 \\
MCH & 32.55 & 30.40 & 32.91 & 35.16 & 28.28 & 33.14 & 35.73 & 32.94 & 34.36 & 34.43 & 31.66 & 0.7865 \\
MCHC & 24.29 & 23.85 & 22.76 & 23.62 & 23.32 & 24.46 & 23.09 & 25.79 & 24.38 & 25.78 & 23.46 & 0.4885 \\
WBCCount & 7.50 & 7.45 & 5.40 & 4.35 & 6.23 & 5.18 & 4.55 & 4.75 & 6.88 & 5.50 & 6.13 & 0.3254
\end{tabular}

a - d: Means in the same row with different superscripts are significantly different from one another $(\mathbf{P}<\mathbf{0 . 0 5})$

Table 7: Serum Chemistry of Broiler Chickens Fed Varying Levels of Cassava Root Meal as Replacement for

\begin{tabular}{|c|c|c|c|c|c|c|c|c|c|c|c|c|}
\hline Parameters & $T \times 1$ & $T \times 2$ & $T \times 3$ & $T \times 4$ & $T \times 5$ & $T \times 6$ & T 77 & $T \times 8$ & T $\times 9$ & $\mathrm{~T} \times 10$ & $T \times 11$ & (SEM) \\
\hline AST & $124.57^{\mathrm{bc}}$ & $115.40^{2 b c}$ & $113.91^{\text {stx }}$ & $131.52^{\circ}$ & $131.52^{\circ}$ & $99.03^{\mathrm{sb}}$ & $100.27^{55}$ & $103.50^{35}$ & $100.77^{\mathrm{sb}}$ & $91.34^{2}$ & $102.23^{\text {sb }}$ & 2.9706 \\
\hline ALT & $8.09^{\mathrm{sb}}$ & $9.85^{\mathrm{ab}}$ & $10.73 \mathrm{ab}$ & $5.97^{\mathrm{ab}}$ & $10.20^{2 \mathrm{~b}}$ & $11.96^{\mathrm{ab}}$ & $5.09^{\mathrm{a}}$ & $8.26^{26}$ & $7.91^{\mathrm{sb}}$ & $7.03^{\mathrm{sb}}$ & $14.26^{\circ}$ & 0.7977 \\
\hline CREATINE & $0.37^{\mathrm{sb}}$ & $0.33^{8}$ & $0.20^{3 b}$ & $0.31^{\mathrm{sb}}$ & $0.14^{3}$ & $0.35^{\mathrm{ab}}$ & $0.29^{2 b}$ & $0.23^{\mathrm{sb}}$ & $0.39^{\circ}$ & $0.37^{\mathrm{sb}}$ & $0.41^{\circ}$ & 0.0233 \\
\hline GLUCOSE & $188.86^{\text {th }}$ & $164.59^{25 b}$ & $174.67^{\mathrm{ab}}$ & $208.22^{\circ}$ & $123.81^{\text {sb }}$ & $179.31^{\text {sb }}$ & $171.75^{\text {sb }}$ & $116.01^{2}$ & $201.18^{\circ}$ & $196.42^{2 \mathrm{~b}}$ & $205.71^{\mathrm{c}}$ & 8.3583 \\
\hline ALBUMIN & $1.28^{\mathrm{sc}}$ & $1.48^{\circ}$ & $1.20^{\mathrm{sc}}$ & $1.21 \mathrm{~b}^{\mathrm{e}}$ & $1.26^{\mathrm{sc}}$ & $1.14^{\mathrm{sbc}}$ & $1.05^{\mathrm{sb}}$ & $1.14^{\mathrm{sbc}}$ & $0.77^{\mathrm{a}}$ & $1.08^{\mathrm{abc}}$ & $0.90^{2 \mathrm{~b}}$ & 0.0474 \\
\hline GLOBULIN & $1.67^{a b}$ & $1.91^{\mathrm{bc}}$ & $1.35^{\mathrm{ab}}$ & $1.37^{\mathrm{ab}}$ & $1.52^{\mathrm{ab}}$ & $1.22^{\mathrm{a}}$ & $1.47^{\mathrm{ab}}$ & $1.33^{\mathrm{ab}}$ & $1.47^{\mathrm{ab}}$ & $1.32^{\mathrm{sb}}$ & $2.28^{\mathrm{bc}}$ & 0.0754 \\
\hline TOTAL PROTEINS & $2.94^{\mathrm{bc}}$ & $3.39^{\circ}$ & $2.5 \mathrm{~g}^{\mathrm{abc}}$ & $2.57^{\mathrm{abc}}$ & $2.78^{\mathrm{abc}}$ & $2.36^{\mathrm{sb}}$ & $2.52^{\mathrm{sb}}$ & $2.47^{\mathrm{ab}}$ & $2.24^{2}$ & $2.40^{2 b}$ & $3.18^{\mathrm{c}}$ & 0.0846 \\
\hline ALP (VALID N) & 152.28 & 217.16 & 152.28 & 152.28 & 152.28 & 152.28 & 152.28 & 152.28 & 182.82 & 224.31 & 152.28 & 8.1103 \\
\hline
\end{tabular}

a - d: Means in the same row with different superscripts are significantly different from one another $(\mathbf{P}<\mathbf{0 . 0 5})$

Table 8: Cost Implication of Feeding Broiler Diets Containing Varying Levels of Cassava Root Meal (Garri) as Replacement for Maize.

\begin{tabular}{|c|c|c|c|c|c|c|c|c|c|c|c|c|}
\hline Parameter & Txl & Tx2 & Tx3 & Tx4 & Tx5 & Tx6 & Tx7 & Tx8 & Tx9 & Tx10 & Txll & SEM \\
\hline Cost $/ \mathrm{kg}$ feed $(\nexists)$ & $136.87^{2}$ & $139.21^{b}$ & $143.55^{\circ}$ & $143.90^{\circ}$ & $146.24^{\circ}$ & $148.59^{\circ}$ & $150.93^{f}$ & $153.27 \mathrm{~s}$ & $155.62^{2}$ & $157.96^{4}$ & $160.30^{j}$ & 1.59 \\
\hline $\begin{array}{l}\text { Cost/total feed } \\
\text { consumed } \cong\end{array}$ & $707.89^{\mathrm{a}}$ & $77094^{\circ}$ & $803.30^{\mathrm{be}}$ & $810.59^{\mathrm{bc}}$ & $820.33^{b c}$ & $824.38^{\mathrm{bc}}$ & $862.64^{d}$ & $811.19^{\mathrm{bc}}$ & $839.96^{\mathrm{bc}}$ & $845.80^{\mathrm{be}}$ & $815.53^{\mathrm{bc}}$ & 10.13 \\
\hline Cost $/ \mathrm{kg}$ weight & $194.64^{2}$ & $276.17^{\mathrm{bc}}$ & $336.85^{\text {cd }}$ & $374.45^{\text {cd }}$ & $411.49^{\circ}$ & $359.36^{\circ 6}$ & $392.87^{\circ}$ & $361.34^{\text {ळ }}$ & $358.23^{\text {d }}$ & $397.87^{\circ}$ & $391.35^{\circ}$ & 14.64 \\
\hline Revenue $(\Rightarrow)$ Bird & $2170.00^{2}$ & $1995.00^{\mathrm{a}}$ & $1715.00^{b}$ & $1575.00^{b}$ & $1435.00^{\circ}$ & 1645.00 & $1575.00^{6}$ & $1610.00^{\mathrm{b}}$ & $1645.00^{\circ}$ & $1540.00^{b}$ & $1505.00^{\circ}$ & 49.37 \\
\hline Gross margin & $1462.11^{2}$ & $1224.06^{\mathrm{a}}$ & $911.71^{\mathrm{b}}$ & $764.41^{b}$ & $614.67^{b}$ & $820.62^{b}$ & $712.36^{\mathrm{b}}$ & $798.82^{\mathrm{b}}$ & $805.04^{b}$ & $694.20^{b}$ & $689.48^{b}$ & 56.96 \\
\hline
\end{tabular}

a - d: Means in the same row with different superscripts are significantly different from one another $(\mathbf{P}<\mathbf{0 . 0 5})$ 